\title{
The Impact of Higher Education and Human Capital Quality on "Local- Neighborhood" Economic Growth
}

\author{
Ran Zhao, Yuhong Du \\ Beijing Normal University, Beijing 100875, China
}

\begin{abstract}
Based on China's provincial panel data from 1990 to 2017 and the improved Lucas, Nelson \& Phelps model, the Spatial Dubin Model is used to test the spatial effects of higher education and human capital quality. The results showed that high-level human capital, characterized by higher education and urban labor income index, indirectly promoted local economic growth through technological innovation. There was also a "local-neighborhood" synergy effect. The neighborhood effect was manifested in that it affected the economic development of neighbors by promoting technological catch-up. After considering the quality factor, both the local and neighborhood effects were enhanced. From a regional perspective, higher education in the Yangtze River Delta, where the level of economic development is relatively high, was manifested as a spatial spillover effect of technological innovation and the neighborhood effect in the northeastern Bohai Rim and the Pearl River Delta was manifested as a technological catch-up.
\end{abstract}

Best Evidence in Chinese Education 2021; 8(1):1041-1057.

Doi: 10.15354/bece.21.ar22.

How to Cite: Zhao, R., \& Du, Y. (2021). The Impact of higher education and human capital quality on "local-neighborhood" economic growth. Best Evidence in Chinese Education, 8(1):1041-1057.

Keywords: Higher Education, Human Capital Quality, Economic Growth, Spatial Dubin Model 
Zhao \& Du. Higher Education, Human Capital Quality and "Local-Neighborhood" Economy.

About the Authors: Ran Zhao, Lecturer, Faculty of Education/Institute of Educational Economics, Beijing Normal University, Beijing 100875, China. Email: zhaoran@bnu.edu.cn

Correspondence to: Yuhong Du, Professor, Faculty of Education/Institute of Educational Economics, Beijing Normal University, Beijing 100875, China.Email: dyh@bnu.edu.cn

Funding: This study was supported by the Ministry of Education's Philosophy and Social Science Major Research Project (15JZD040) and the Central Government's Special Fund for Basic Scientific Research in Universities (2019NTSSO6).

Conflict of Interests: None.

(C) 2021 Insights Publisher. All rights reserved.

(c) (i) (s) Creative Commons Non Commercial CC BY-NC: This article is distributed under the terms of the Creative Commons Attribution-NonCommercial 4.0 License (http://www.creativecommons.org/licenses/by$\mathrm{nc} / 4.0 /$ ) which permits non-commercial use, reproduction and distribution of the work without further permission provided the original work is attributed by the Insights Publisher. 


\section{Introduction}

$\mathrm{F}$ IROM 1978 to 2010, the Chinese economy maintained an average annual growth rate of more than $10 \%$, creating a growth miracle that attracted worldwide attention. After 2010, the growth rate has gradually slowed down, and the GDP growth rate from 2017 to 2019 was below 7\%. The economy has transformed from high-speed growth in the past to medium- and high-speed growth. China's "demographic dividend" advantage is gradually diminishing. Labor shortage and population aging have gradually become key factors restricting economic growth. As a comprehensive indicator to measure population size, structure, and quality, human capital determines national and regional economic development speed and quality. From 1982 to 2017, the proportion of the population with an associate degree education and above in the Chinese labor force showed a significant upward trend increased from $0.9 \%$ in 1982 to $18 \%$ in 2017. The decline in the number of labor forces will not be conducive to economic growth, but can the improvement in labor quality make up for the growing gap caused by the decline in the number of labor forces?

What is the mechanism and realization path of higher education's influence on regional economic growth? Does this impact show spatial dependence characteristics among regions with significant differences in population size, education quality, and economic development? Previous studies adopted the average years of education or the total years of education, which could not reflect the change in the quality of the labor force. Our study used the revised Lucas and Nelson \& Phelps models for spatial econometric analysis by constructing two data sets of labor income index human capital and education human capital (Lucas, 1988); Nelson \& Phelps, 1965). This helps to understand the spatial mechanism of higher education and human capital quality from a deeper level and provides a decision-making reference for implementing the coordinated development of China's higher education and regional economy to a certain extent.

\section{Literature Review}

\section{The Mechanism and Direction of Human Capital in Economic Growth}

Research under the macro-framework mainly focuses on the mechanism of education and human capital in economic growth and the direction and significance of human capital in economic growth. There are primarily the following views on the mechanism: Firstly, human capital directly participates in the production process as a production factor that improves the quality of labor, and the accumulation of specialized human capital is the decisive factor in promoting sustained economic growth (Lucas, 1988). Secondly, human capital promotes the indirect effects of economic growth by fostering technological innovation and technological catch-up, emphasizing that the stock of human capital is a critical factor in economic growth (Romer, 1990; Ding \& Knight, 2011; 
Li et al., 2016). Thirdly, human capital directly affects output as a factor and indirectly promotes a joint mechanism of economic growth by promoting technological innovation and imitating absorption (Engelbrecht, 2003; Du et al., 2014). Fourthly, from a regional perspective, some studies have confirmed that education and human capital have positive spatial externalities (Chang \& Zhao, 2017; Deng \& Ke, 2020), but some studies have reached the opposite conclusion (Fischer et al., 2009). It can be seen that the mechanism of different levels of education and human capital in space still needs to be further tested.

\section{"Stock" and "Quality" in Human Capital Measurement}

In the research on the relationship between education, human capital, and economic growth, a vital issue is distinguishing between "stock" and "quality" in human capital. The more mature human capital measurement methods mainly include cost method, income method, and education characteristic method. The main idea of the cost method is to compare the method of measuring physical capital. Most scholars estimate the stock of human capital in various countries or different periods based on perpetual inventory technology (Schultz, 1961; Kendrick, 1976; Qian, 2012; Meng \& Wang, 2014). Previous studies on the impact of education on economic growth have focused more on quantitative educational indicators. The commonly used proxy variables include the average years of workers' education (Psacharopoulos \& Patrinos, 2004; Barro \& Lee, 1993 ) and the adult literacy rate (Cai \& Du, 2000). Studies have also shown that once the factors of education quality (international test scores, etc.) are considered, the influence of the quantity of education becomes insignificant. In contrast, the quality of education has a strong positive effect on economic growth (Jamison et al., 2007; Hanushek \& Woessmann, 2011). Still, the use of international test scores cannot directly measure the human capital level of the working-age population (Graham \& Webb, 1979). There are two ways to use the income method to calculate human capital: one is to use the sum of the present value of future income to measure human capital (Jorgenson \& Fraumeni, 1989; Li \& Tang, 2015; Dong, 2017). However, it is impossible to eliminate the influence of the annual increase in physical capital on the stock of human capital. The other is to estimate human capital by using the present value income of workers. The most representative is LIHK (Labor-Income-Based Human Capital) labor income method (Mulligan \& Sala-i-Martin, 1997). It reflects the difference of different education levels, the change of education quality over time, and factors such as work experience on human capital accumulation. Simultaneously, it effectively eliminates the influence of physical capital on the measurement, which is more reasonable for analyzing economic growth (Zhu \& Xu, 2007; Liang et al., 2015).

Based on the concept of unit human capital in the income method, this research constructs two types of panel data: human capital index and educational human capital, including scale, structure, and quality. By establishing a spatial measurement model, the spatial effect mechanism of higher education and human capital quality in economic growth is tested under the premise of fully considering spatial and geographical factors. 


\section{Human Capital Measurement Based on LIHK Income Method}

According to China's primary data, we first need to estimate the annual population data according to gender, age, urban and rural areas, and education level. Secondly, we need to evaluate the income of each part of the group. Using the method of the China Human Capital and Labor Economics Research Center (CHLR), we estimated the expanded Mincer income equation (1):

$$
\begin{gathered}
\ln (\text { wage })=\alpha+\beta_{1} S c h+\beta_{2} E x p+\beta_{3} E x p^{2}+\beta_{4} S c h \cdot \text { ave_gdp }+\beta_{5} S c h \\
\cdot \text { indus_gdp }+\beta_{6} \text { ave_wage }+\beta_{7} \text { male }+\beta_{8} \text { urban }
\end{gathered}
$$

Where $\ln$ (wage) is the natural logarithm of income. Sch represents the number of years of education. Exp is an individual's work experience. ave_gdp represents the per capita GDP of the province. indus_gdp indicates the proportion of tertiary industry output value in GDP in the province where it is located. ave_wage represents the average wage level in the province. According to the two databases of CHNS (China Health and Nutrition Survey, 1989-2015) and CFPS (China Family Panel Studies, 2010-2016), the weighted results based on the sample size yield the intercept term, Sch, Exp, and the coefficient of $\operatorname{Exp}^{2}$. Then, the linear fitting of the variable to the time trend is made, and the fitting value of the missing year is obtained. Then the human capital index of the individual by sex, age, urban and rural, and education level was calculated. The total human capital stock is obtained by adding up the number of labor forces in each group.

\section{Construction of Spatial Panel Data Measurement Model}

\section{Research Method}

The two basic setting methods for spatial interaction are: one is Spatial Lag Model (SLM) (Lagged Dependent Variable), and the other is Spatial Error Model (SEM) (The error term contains a Spatial Autoregression process). Spatial Dubin Model (SDM) is a general form of the spatial measurement model and a broader SLM and SEM measurement model. Among them, $\mathrm{y}_{\mathrm{it}}$ is the explained variable, $\mathrm{x}_{\mathrm{it}}$ is the explanatory variable, and the primary expression of the model is:

SLM:

$$
y_{i t}=\mu_{i}+\alpha_{t}+\eta \sum_{j=1}^{N} w_{i j} y_{i t}+\lambda x_{i t}+\varepsilon_{i t}
$$


SEM:

$$
\begin{gathered}
y_{i t}=\mu_{i}+\alpha_{t}+\lambda x_{i t}+\varepsilon_{i t} \\
\varepsilon_{i t}=\rho \sum_{j=1}^{N} w_{i j} \varepsilon_{i j}+v_{i t}
\end{gathered}
$$

SDM:

$$
y_{i t}=\mu_{i}+\alpha_{t}+\eta \sum_{j=1}^{N} w_{i j} y_{i t}+\lambda \sum_{j=1}^{N} w_{i j} x_{i t}+\varepsilon_{i t}
$$

This study draws on the model of Lucas and Nelson \& Phelps (Lucas, 1988; Nelson \& Phelps, 1965), combined with the improved research framework of Yuhong Du et al. (Du \& Zhao, 2018), to test the spatial effect mechanism of higher education and human capital quality on economic growth. We hypothesized that different levels of human capital have different growth paths: basic human capital influences growth by increasing factor accumulation. In contrast, advanced human capital promotes growth by promoting technological innovation and imitating catch-up. We set the production function to the following form:

$$
Y=A(H a) K^{\alpha} H b^{\beta} L^{\gamma}
$$

Y represents output, K represents capital, Ha represents high-level human capital, $\mathrm{Hb}$ represents basic human capital, L represents labor force. A means technological progress rate or total factor productivity.

Drawing on the study of Nelson \& Phelps (Nelson \& Phelps, 1965), Ha represents technological innovation and $\mathrm{Ha} * \frac{\mathrm{y}_{\max }-\mathrm{y}}{\mathrm{y}}$ means technological imitation and catch-up, as shown in equation (6):

$$
A(H a)=A_{0} \exp \left(c+g * H a+\delta H a * \frac{y_{\max }-y}{y}\right)
$$

Take the per capita form and digitize both sides of equation (5) at the same time, and add the spatial effect after substituting equation (6) to obtain the spatial panel model (7): 


$$
\begin{aligned}
\ln \left(y_{i t}\right)=c+\beta & \ln \left(k_{i t}\right)+\gamma \ln \left(h b_{i t}\right)+\theta \ln \left(L_{i t}\right)+h a+\delta h a\left(y_{\max }-y_{i 0}\right) / y_{i 0} \\
& +\varphi Z_{i t}+\alpha_{i}+\sigma \sum_{j=1}^{N} w_{i j} \ln \left(k_{i t}\right)+\varsigma \sum_{j=1}^{N} w_{i j} \ln \left(h b_{i t}\right) \\
& +\tau \sum_{j=1}^{N} w_{i j} \ln \left(L_{i t}\right) \\
& +v \sum_{j=1}^{N} w_{i j} h a_{i t}+\psi \sum_{j=1}^{N} w_{i j} h a_{i t}\left(y_{\text {max }}-y_{i 0}\right) / y_{i 0}+\varepsilon_{i t}
\end{aligned}
$$

Among them, the explained variable is represented by GDP per capita, and the explanatory variables include physical capital (k), number of laborers (L), basic human capital (hb), advanced human capital (ha), technological imitation, and catch-up (Catch), representing a series of Control variables include foreign trade dependence (open), industrial structure (indus), and government support (gov). c, $\alpha_{\mathrm{i}}$, and $\varepsilon_{\mathrm{it}}$ represent a constant term, a regional fixed effect, and a random error term, respectively. $\mathrm{w}_{\mathrm{ij}}$ represents the elements of the spatial weight matrix. This study uses three types of matrices for analysis.

The adjacency weight matrix $\mathrm{W} 1$ is constructed by studying whether the variables are adjacent to each other by assigning values of 0 or 1 . If $i=j$, it means that province $i$ and $j$ are adjacent; if $i \neq j$, it means that province $i$ and $j$ are not adjacent.

$$
w_{i j}=\left\{\begin{array}{l}
0, i=j \\
1, i \neq j
\end{array}\right.
$$

Besides, in order to test the robustness of the estimation results, we also consider the attenuation of the spatial effect as the distance increases and construct the geographical distance weight matrix W2:

$$
w_{i j}=\left\{\begin{array}{c}
0, i=j \\
1 / d_{i j}^{2}, i \neq j
\end{array}\right.
$$

At the same time, to objectively express the spatial correlation of the economic development level of the spatial unit, we also construct the economic distance weight matrix W3, where $\bar{y}_{i}$ is the average GDP of the region i over the years, and $\bar{y}$ is the average GDP of the full sample.

$$
w_{3}=w_{2} \times \operatorname{diag}\left(\bar{y}_{1} / \bar{y}, \bar{y}_{2} / \bar{y}, \cdots, \bar{y}_{n} / \bar{y}\right)
$$




$$
\bar{y}_{i}=\frac{1}{t_{1}-t_{0}+1} \sum_{t=t_{0}}^{t_{1}} y_{i t}, \bar{y}=\frac{1}{n\left(t_{1}-t_{0}+1\right)} \sum_{i=1}^{n} \sum_{t=t_{0}}^{t_{1}} y_{i t}
$$

\section{Data Sources and Variables}

According to the availability of samples, this paper selects the panel data of 30 provinces from 1990 to 2017 as the research sample (the Tibet Autonomous Region has been eliminated due to excessive data missing). The data we used to measure LIHK's human capital came from "China's 1982 Census", "China's 1990 Census", "China's 2000 Census", "China's 2010 Census", "China Demographic Yearbook (1991-2018)", the provincial census data and statistical yearbooks, the China Nutrition and Health Survey (CHNS, 1989-2015) and the Chinese Family Panel Studies (CFPS, 2010-2016) microdatabase; the original data of other variables were from the "China Statistical Yearbook" (1991-2018)", "China Labor Statistics Yearbook (1991-2018)" and statistical yearbook of each province.

- Output Level (Y/y)

The output level reflects the economic development status of a province and is expressed by the province's gross regional product $(\mathrm{Y})$ and per capita gross regional product (y).

- Capital Stock (K) / Capital Stock per Capita (k)

As there are currently no official statistics on annual physical capital stock data, the most commonly used calculation method is the Perpetual Inventory Method. The interprovincial material capital stock data used in this article came from Holz and Dr. Sun Yue (Holz \& Sun, 2018).

- Human Capital

We measured human capital in two forms: years of education and LIHK Human Capital Index. Advanced human capital (ha) is equal to the sum of years of education of all workers with higher education, and basic human capital (hb) is equal to the sum of years of education of all workers with elementary, middle, and high school education. This study also measured the human capital index based on the LIHK labor income method, reflecting the comprehensive effect of labor force size and quality. Considering the conditions in rural areas in China, they usually only have limited opportunities for higher education, and it is difficult for them to have the opportunity to obtain advanced skills from their jobs. Therefore, the main reason for the urban-rural income gap can be attributed to the difference in advanced human capital levels. The measured rural labor income index and urban labor income index were used as substitute variables for basic (hb_LIHK) and advanced human capital (ha_LIHK). 


\section{- $\quad$ Other Control Variables}

Foreign trade dependence (open), industrial structure (indus), and government support (gov) respectively used the proportion of total regional imports and exports to GDP, the ratio of the added value of the tertiary industry to GDP, and the balance of government public budget fiscal expenditures in GDP.

\section{Empirical Result Analysis}

\section{Preliminary Test of Spatial Effect Model}

Before estimating the model, it was necessary to test whether there was a spatial effect between the quality of higher education and human capital and economic growth (shown in Table 1). Both the Lagrange multiplier test and robust test results rejected the null hypothesis that there was no spatial lag effect or spatial error effect. It showed that there was a significant spatial dependence characteristic between higher education, human capital quality, and economic growth in various regions. The Wald statistics of spatial lag and spatial error were both significant at the $1 \%$ statistical level, indicating that the Spatial Dubin Model's null hypothesis could be transformed into a spatial lag or error model should be rejected, so it was more appropriate to establish the Spatial Dubin Model. Simultaneously, the Hausman test result passes the $1 \%$ significance test, and a fixed-effect Spatial Dubin Model (SDM-FE) should be established. Considering that China's education, human capital level, and economic growth all present significant imbalanced characteristics, the mixed effects and time fixed effects ignore regional structural economic differences. In contrast, the space-time double fixed-effect model can simultaneously consider regional spatial differences and period effects, further effectively distinguish the role of spatial dependence from the impact of spatial heterogeneity and omitted variables. Studies have pointed out that the parameters obtained using Maximum Likelihood Estimation (MLE) were asymptotically effective (Chen, 2014). Therefore, we used the Spatial Dubin Model with dual fixed MLE time and space.

\section{Model Estimation Results}

The estimation results obtained under the three spatial weight matrices of the national adjacency matrix, inverse distance matrix, and economic distance matrix were relatively stable (shown in Table 2). Most of the coefficient estimates had not changed significantly, indicating the robustness of the estimated results. Simultaneously, the best fit of the model was assessed under the economic distance matrix, indicating that the spatial effect of education and human capital quality on economic growth was more reflected in economic spatial connections. Therefore, in the following, we mainly analyzed the economic distance matrix W3. The estimated values of advanced human capital (variables ha and ha_LIHK) were both positive at the $1 \%$ significance level, indicating that advanced human capital represented by higher education (ha) could significantly pro mote regional economic growth through technological innovation effects and urban 
Table 1. The Spatial Effect Test of Higher Education and Human Capital Quality in Economic Growth.

\begin{tabular}{|c|c|c|c|}
\hline Test & W1 & W2 & W3 \\
\hline Lagrange Multiplier Test (Spatial Lag) & $7.857^{\star \star *}(0.005)$ & $9.529^{* * *}(0.002)$ & $4.279^{* *}(0.039)$ \\
\hline Robust Lagrange multiplier test (Spatial Lag) & $7.047^{\star \star \star}(0.008)$ & $8.746^{\star * *}(0.003)$ & $4.052^{* *}(0.044)$ \\
\hline Lagrange Multiplier Test (Spatial Error) & $16.072^{\star * \star}(0.005)$ & $8.031^{\star \star *}(0.005)$ & $3.231^{*}(0.072)$ \\
\hline Robust Lagrange multiplier test (Spatial Error) & $15.262^{* * *}(0.005)$ & $7.248^{* * *}(0.007)$ & $3.004^{*}(0.082)$ \\
\hline Wald Test (Spatial Lag) & $83.06^{\star \star \star}(0.000)$ & $240.39^{* * *}(0.000)$ & $100.24^{* \star *}(0.000)$ \\
\hline Wald Test (Spatial Error) & $82.52^{* \star *}(0.000)$ & $154.71^{* * *}(0.000)$ & $53.03^{\star * *}(0.000)$ \\
\hline Hausman Test & $346.48^{* * *}(0.000)$ & $34.81^{* \star *}(0.000)$ & $95.33^{\star * *}(0.000)$ \\
\hline
\end{tabular}

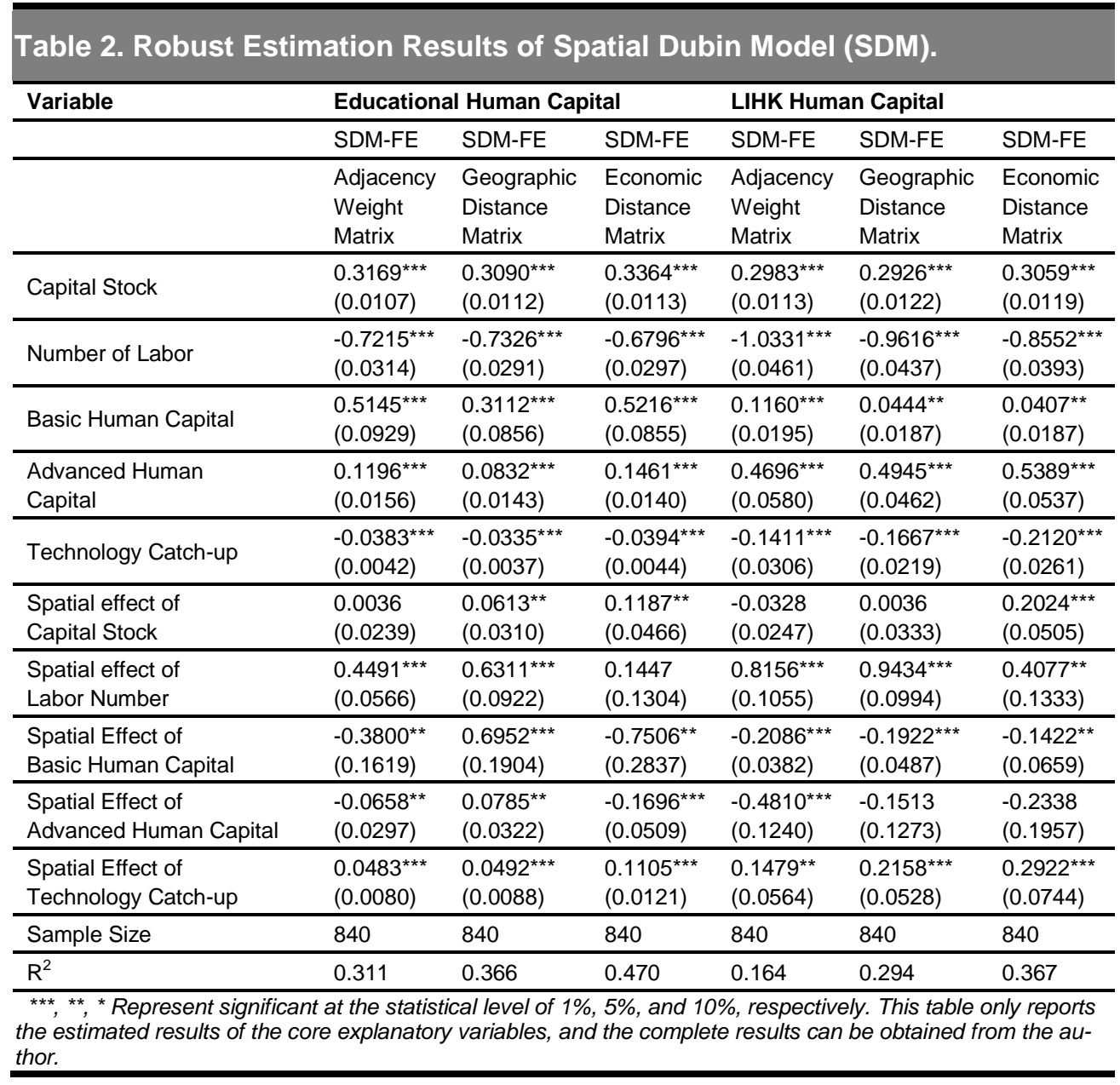


labor quality factor (ha_LIHK) included in the income index had a more substantial impact on local economic growth. The estimated value of the spatial effect of advanced human capital is negative, and it is only significant under the human capital index measured by education level. The estimated value of the spatial impact of technological catch-up is positive at the $1 \%$ significance level, indicating that although the flow of technology and personnel and other factor resources have produced spatial spillover effects, the spillover effects of high-level human capital are mainly realized as technological imitation and catch-up. Since the estimation results of the SDM model cannot fully reflect the relationship between the explained variables and the explanatory variables, according to the research of Lesage and Pace (LeSage \& Pace, 2009), the use of partial differential methods could better deal with the error of spatial spillover effect estimation. The partial differentiation method decomposed the Spatial Dubin Model (SDM) total spatial spillover effects into direct and indirect effects. The total effect was the sum of the immediate impact and the indirect effect.

Table 3 reports the estimated results of the local direct effects, the indirect impact of neighbors, and the total effects of higher education and human capital quality under the economic distance matrix. Different levels of human capital have other spatial mechanisms for economic growth. Among them, essential human capital directly affects local economic growth through the production of final products, but it will inhibit the economic growth of neighboring provinces. The local effect coefficient of highlevel human capital, characterized by higher education and urban labor income index, which promotes economic growth through technological innovation, is significantly positive, confirming the mechanism of high-level human capital indirectly promoting regional economic growth through technological innovation. And for every year of higher education years, the growth effect brought by technological innovation in the region will increase by $0.15 \%$. The level of high-level human capital, including quality factors, will increase by one unit. The economic growth brought by technological innovation in the region will increase by $0.55 \%$. It shows that compared with the quantity of education, quality factors can promote economic growth in the region. The spillover effect of advanced human capital through technological innovation in promoting the growth of neighboring areas was not significant or significantly negative, which may be due to the "Matthew effect" existing in the advanced human capital level of different provinces, which makes it impossible to form the spillover effect of technological innovation. The spatial spillover effect of advanced human capital was mainly manifested in improving the economic growth level of neighboring regions through the promotion of technological imitation and catch-up. The impact of technological catch-up to promote the growth of neighboring areas was $0.11 \%-0.29 \%$. Therefore, to realize the leapfrog transformation of the spatial spillover effect of higher education from technological imitation and absorption to high-end technological innovation, it is also necessary to rely on higher levels of education and human capital. Improving the quality of education is the key to promoting the coordinated development of higher education and the regional economy. 
Table 3. Decomposition of the Spatial Effect of Higher Education and Human Capital Quality in Promoting Regional Economic Growth.

\begin{tabular}{|c|c|c|c|c|c|c|}
\hline \multirow[t]{2}{*}{ Variable } & \multicolumn{2}{|c|}{ Local Effect } & \multicolumn{2}{|c|}{ Neighborhood Effect } & \multicolumn{2}{|c|}{ Overall Effect } \\
\hline & $\begin{array}{l}\text { Education } \\
\text { Level }\end{array}$ & LIHK & $\begin{array}{l}\text { Education } \\
\text { Level }\end{array}$ & LIHK & $\begin{array}{l}\text { Education } \\
\text { Level }\end{array}$ & LIHK \\
\hline Capital Stock & $\begin{array}{l}0.3355^{\star \star \star} \\
(0.0115)\end{array}$ & $\begin{array}{l}0.3033^{\star * \star} \\
(0.0123)\end{array}$ & $\begin{array}{l}0.0716^{\star *} \\
(0.0358)\end{array}$ & $\begin{array}{l}0.1299^{\star \star \star} \\
(0.0388)\end{array}$ & $\begin{array}{l}0.4070^{\star * \star} \\
(0.0365)\end{array}$ & $\begin{array}{l}0.4332^{* \star *} \\
(0.0403)\end{array}$ \\
\hline Number of Labor & $\begin{array}{l}-0.6850^{\star * *} \\
(0.0269) \\
\end{array}$ & $\begin{array}{l}-0.8687^{\star \star \star} \\
(0.0358) \\
\end{array}$ & $\begin{array}{l}0.2061^{*} \\
(0.1179)\end{array}$ & $\begin{array}{l}0.4841^{\star * *} \\
(0.1162)\end{array}$ & $\begin{array}{l}-0.4790^{* * *} \\
(0.1133) \\
\end{array}$ & $\begin{array}{l}-0.3846^{\star \star \star} \\
(0.1153)\end{array}$ \\
\hline Basic Human Capital & $\begin{array}{l}0.5351^{* * *} \\
(0.0925) \\
\end{array}$ & $\begin{array}{l}0.0456^{\star *} \\
(0.0186)\end{array}$ & $\begin{array}{l}-0.7291^{* *} \\
(0.3054) \\
\end{array}$ & $\begin{array}{l}-0.1265^{\star *} \\
(0.0611) \\
\end{array}$ & $\begin{array}{l}-0.1940 \\
(0.2830) \\
\end{array}$ & $\begin{array}{l}-0.0809 \\
(0.0630) \\
\end{array}$ \\
\hline $\begin{array}{l}\text { Advanced Human } \\
\text { Capital }\end{array}$ & $\begin{array}{l}0.1499^{\star * *} \\
(0.0152) \\
\end{array}$ & $\begin{array}{l}0.5493^{\star * *} \\
(0.0578) \\
\end{array}$ & $\begin{array}{l}-0.1715^{\star *} \\
(0.0528) \\
\end{array}$ & $\begin{array}{l}-0.2953 \\
(0.1848)\end{array}$ & $\begin{array}{l}-0.0216 \\
(0.0487)\end{array}$ & $\begin{array}{l}0.2540 \\
(0.1878)\end{array}$ \\
\hline Technology Catch-up & $\begin{array}{l}-0.0416^{\star * *} \\
(0.0050)\end{array}$ & $\begin{array}{l}-0.2212^{\star * *} \\
(0.0295)\end{array}$ & $\begin{array}{l}0.1058^{\star * \star} \\
(0.0129)\end{array}$ & $\begin{array}{l}0.2934^{\star \star \star} \\
(0.0752)\end{array}$ & $\begin{array}{l}0.0642^{\star * \star} \\
(0.0115)\end{array}$ & $\begin{array}{l}0.0722 \\
(0.0674)\end{array}$ \\
\hline $\begin{array}{l}\text { Foreign Trade Degree } \\
\text { of Dependence }\end{array}$ & $\begin{array}{l}0.0436^{\star \star} \\
(0.0144)\end{array}$ & $\begin{array}{l}-0.0028 \\
(0.0159)\end{array}$ & $\begin{array}{l}0.0455 \\
(0.0386)\end{array}$ & $\begin{array}{l}-0.0781^{*} \\
(0.0449)\end{array}$ & $\begin{array}{l}0.0891^{* *} \\
(0.0382)\end{array}$ & $\begin{array}{l}-0.0808^{*} \\
(0.0477)\end{array}$ \\
\hline Industrial Structure & $\begin{array}{l}-0.3621^{\star \star \star} \\
(0.0639)\end{array}$ & $\begin{array}{l}-0.3022^{\star \star \star} \\
(0.0623)\end{array}$ & $\begin{array}{c}-0.0902 \\
(0.2330)\end{array}$ & $\begin{array}{l}0.0419 \\
(0.2219)\end{array}$ & $\begin{array}{l}-0.4523^{*} \\
(0.2402)\end{array}$ & $\begin{array}{l}-0.2604 \\
(0.2352)\end{array}$ \\
\hline Government Support & $\begin{array}{l}-0.4233^{\star \star \star} \\
(0.0623)\end{array}$ & $\begin{array}{l}-0.3146^{\star \star \star} \\
(0.0692)\end{array}$ & $\begin{array}{c}-0.3324^{*} \\
(0.1833)\end{array}$ & $\begin{array}{l}0.3758^{\star *} \\
(0.1828)\end{array}$ & $\begin{array}{l}-0.7558^{* * *} \\
(0.1774)\end{array}$ & $\begin{array}{l}0.0612 \\
(0.1710)\end{array}$ \\
\hline
\end{tabular}

Table 4. Estimation of the Spatial Effect of Higher Education by Dividing Economic Zones.

\begin{tabular}{|c|c|c|c|c|c|c|}
\hline & \multicolumn{2}{|c|}{$\begin{array}{l}\text { Bohai Sea Economic } \\
\text { Belt and Northeast China }\end{array}$} & \multicolumn{2}{|c|}{$\begin{array}{l}\text { Yangtze River Triangle } \\
\text { Economic Belt }\end{array}$} & \multicolumn{2}{|c|}{$\begin{array}{l}\text { Pearl River Delta } \\
\text { Economic Belt }\end{array}$} \\
\hline & Local & Neighborhood & Local & Neighborhood & Local & Neighborhood \\
\hline $\begin{array}{l}\text { Capital } \\
\text { Stock }\end{array}$ & $\begin{array}{l}0.4932^{* * *} \\
(0.0212) \\
\end{array}$ & $\begin{array}{l}-0.1160^{*} \\
(0.0687)\end{array}$ & $\begin{array}{l}0.1341^{* * *} \\
(0.0190)\end{array}$ & $\begin{array}{l}-0.0904^{* *} \\
(0.0416)\end{array}$ & $\begin{array}{l}0.2900^{\star * *} \\
(0.0261) \\
\end{array}$ & $\begin{array}{l}-0.0411 \\
(0.0845)\end{array}$ \\
\hline $\begin{array}{l}\text { Number of } \\
\text { Labor }\end{array}$ & $\begin{array}{l}0.0311 \\
(0.0800) \\
\end{array}$ & $\begin{array}{l}-0.2317 \\
(0.2230) \\
\end{array}$ & $\begin{array}{l}-0.1039^{\star \star \star} \\
(0.0063) \\
\end{array}$ & $\begin{array}{l}0.0439^{\star *} \\
(0.0181) \\
\end{array}$ & $\begin{array}{l}-0.0426^{* \star \star} \\
(0.0050) \\
\end{array}$ & $\begin{array}{l}-0.0841^{* * *} \\
(0.0240) \\
\end{array}$ \\
\hline $\begin{array}{l}\text { Basic Human } \\
\text { Capital }\end{array}$ & $\begin{array}{l}0.1777^{\star * \star} \\
(0.0211) \\
\end{array}$ & $\begin{array}{l}0.1016^{*} \\
(0.0537)\end{array}$ & $\begin{array}{l}-0.0480^{*} \\
(0.0248)\end{array}$ & $\begin{array}{l}0.2370^{\star \star *} \\
(0.0574) \\
\end{array}$ & $\begin{array}{l}0.0499^{\star *} \\
(0.0242)\end{array}$ & $\begin{array}{l}-0.1249^{* * *} \\
(0.0369) \\
\end{array}$ \\
\hline $\begin{array}{l}\text { Advanced } \\
\text { Human } \\
\text { Capital }\end{array}$ & $\begin{array}{l}0.1624^{\star \star *} \\
(0.0290)\end{array}$ & $\begin{array}{l}-0.1099 \\
(0.0753)\end{array}$ & $\begin{array}{l}-0.0239 \\
(0.0358)\end{array}$ & $\begin{array}{l}0.1607^{\star *} \\
(0.0591)\end{array}$ & $\begin{array}{l}0.1853^{* * *} \\
(0.0553)\end{array}$ & $\begin{array}{l}-0.1323 \\
(0.0850)\end{array}$ \\
\hline $\begin{array}{l}\text { Technology } \\
\text { Catch-up }\end{array}$ & $\begin{array}{l}-0.0674^{* * *} \\
(0.0075) \\
\end{array}$ & $\begin{array}{l}0.1659^{\star \star *} \\
(0.0292) \\
\end{array}$ & $\begin{array}{l}0.0471^{* *} \\
(0.0201)\end{array}$ & $\begin{array}{l}0.0575 \\
(0.0369)\end{array}$ & $\begin{array}{l}0.0161 \\
(0.0255)\end{array}$ & $\begin{array}{l}0.1584^{* *} \\
(0.0575)\end{array}$ \\
\hline Sample Size & 252 & & 112 & & 168 & \\
\hline $\mathrm{R}^{2}$ & 0.883 & & 0.362 & & 0.658 & \\
\hline
\end{tabular}

*This table only reports the spatial direct and indirect effects of using W3 matrix and education human capital to estimate core explanatory variables. The complete results can be obtained from the author. In terms of regional division, this article draws on the division method of Tongbin Zhang (2016). Among them, the Bohai Sea Economic Belt and Northeast China include 9 provinces (cities, autonomous regions), including Beijing, Tianjin, Hebei, Shanxi, Inner Mongolia, Liaoning, Jilin, Heilongjiang, and Shandong; the Yangtze River triangle economic belt includes 4 provinces (cities) of Shanghai, Jiangsu, Zhejiang, and Anhui; the Pearl River Delta economic belt includes 6 provinces of Fujian, Jiangxi, Hunan, Guangdong, Guangxi, and Hainan. 


\section{Further Discussion on the Spatial Spillover Effect of Higher Education}

About $70 \%$ of the world's entire economy is from the economic output of more than 40 major urban agglomerations globally. In recent years, China's three major urban agglomerations, the Yangtze River Delta, the Pearl River Delta, and Beijing-TianjinHebei have become the three growth poles of China's economic development and have produced more than $40 \%$ of GDP. We refer to the classification standard of Zhang et al. (Zhang, 2016) to further estimate the sub-samples of the Northeast, Yangtze River Delta, and Pearl River Delta Economic Belts in the Bohai Rim Economic Zone, observe the spatial effects of higher education within the region and make regional comparisons (Table 4). In terms of regional differences, the Yangtze River Delta has the highest per capita GDP during the sample period. The Bohai Rim Economic Belt has a higher per capita GDP than the Pearl River Delta. The technological innovation spillover effect of advanced human capital represented by higher education is significantly positive in the Yangtze River Delta region, indicating that the "agglomeration effect" of the economic belt has brought new momentum to regional economic growth. The neighborhood effect is not significant in the northeastern Bohai Rim region and the Pearl River Delta region. The neighborhood effect of higher education in the northeastern Bohai Rim and the Pearl River Delta is mainly manifested in technology catch-up and imitation. Complying with the "Guangdong-Hong Kong-Macao Greater Bay Area" policy, along with the flow of talents and technologies, higher education has enhanced the ability to absorb and imitate technology in the Pearl River Delta region, promoted the economic growth of neighboring areas, and strengthened the economic growth of higher education throughout the region.

\section{Conclusions and Suggestions}

Using panel data from China's provinces and municipalities from 1990 to 2017, combined with microdata, two human capital measurement data were constructed using the education stock and labor income index method. And learn from the improved Lucas and Nelson \& Phelps models to clarify the mechanism of higher education and human capital quality from the spatial dimension. The results found: (i) Higher education indirectly promotes local economic growth through technological innovation, but the spatial spillover effect is mainly manifested in promoting economic growth in neighboring areas through technological catch-up and imitation. After considering quality factors, the local and neighboring growth effects of advanced human capital are both enhanced. (ii) Basic human capital directly acts on output to promote regional economic growth, but it will inhibit the economic growth of other neighboring provinces and cities. (iii) Higher education exhibits different effects in regions with different economic development levels, and it can, even more, exert a technological innovation spillover effect on economic growth in areas with high economic development levels.

Based on the above research conclusions, the policy implications are as follows: 
Firstly, give full play to the spatial coordination mechanism of higher education that promotes local-neighborhood growth through technological innovation and technological imitation and enhances the contribution of higher education to regional economic growth. When formulating regional development policies, spatial factors should be included. Continuously improve the level and quality of human capital, amplify the agglomeration effect and scale effect, ensure the full use of human capital externalities, and constantly increase the contribution of higher education and human capital to regional economic growth.

Secondly, realize the complementary advantages of provincial education and human capital, and form a regional economic layout with high-quality development. It is necessary to strengthen further the positive spillover effect of human capital in promoting technology imitation and absorption in the region and at the same time enhance the technology assimilation and absorption capacity of neighboring areas. Creating an environment conducive to sharing knowledge within the region and stimulating imitation, absorption, and independent innovation in neighboring areas and the quality of economic development in the entire area are ultimately improved.

Thirdly, implement differentiated policies for regions with different development levels, and build an innovative system for the coordinated development of regional higher education and economy. The external environment for technological innovation and economic growth should be continuously optimized to enable the spillover of the talent innovation effect to break through the limitations of geographical proximity. Open up the path of high-level talent knowledge spillover, improve regional connectivity, realize the matching interaction between high-level innovative talents and the upgrading of regional industrial structure, and form a talent layout conducive to regional coordinated development.

\section{References}

Barro, R.J., \& Lee, J.W. (1993). International comparisons of educational attainment. Journal of Monetary Economics, 32(3):363-394. DOI:

https://doi.org/10.1016/03043932(93)90023-9

Cai, F., \& Du, Y. (2000). Convergence and differences in China's regional economic growth: Implications for the western development strategy. Economic Research Journal, 46(10):30-37+80.

Chang, X., \& Zhao, Y. (2017). An econometric research on the economic growth effect of China's human capital: An empirical analysis based on interprovincial panel data. Journal of Statistics and Information, 32(11):10-20. [Chinese] 
Zhao \& Du. Higher Education, Human Capital Quality and "Local-Neighborhood" Economy.

https://www.cnki.com.cn/Article/CJFD

Total-TJLT201711002.htm

Chen, Q. (2014). Advanced econometrics and Stata application (Second Edition).

Beijing: Higher Education Press. ISBN: 978-7-04-032983-4.

Deng, F., \& Ke, W. (2020). Heterogeneous human capital and economic development: an empirical study based on spatial heterogeneity. Statistical Research, 37(2):93-104. [Chinese]

https://www.cnki.com.cn/Article/CJFD Total-TJYJ202002009.htm

Ding, S., \& Knight, J. (2011). Why has China grown so fast? The role of physical and human capital formation. Oxford Bulletin of Economics \& Statistics, 73(2):141-174. DOI:

https://doi.org/10.1111/j.14680084.2010.00625.x

Dong, Z. (2017). Research on the interactive relationship between human capital and economic growth: An empirical analysis based on China's human capital index. Macroeconomics, 37(4):88-98. [Chinese] DOI: https://doi.org/10.16304/j.cnki.113952/f.2017.04.010

Du, W., Yang, Z., \& Xia, G. (2014). Research on the mechanism of human capital promoting economic growth. China Soft Science, 29(8):173-183. [Chinese] DOI:

https://doi.org/10.3969/j.issn.10029753.2014.08.018

Du, Y., \& Zhao, R. (2018). The role of education in economic growth: factor accumulation, efficiency improvement, or capital complementarity? Educational Research, 39(5):27-35. [Chinese] https://www.cnki.com.cn/Article/CJFD Total-JYYJ201805005.htm

Engelbrecht, H.J. (2003). Human Capital and Economic Growth: Cross-Section Evidence for OECD Countries. Economic Record, 79:40-51. DOI: https://doi.org/10.1111/14754932.00090

Fischer, M.M., Bartkowska, M., Riedl, A., Sardadvar, S., \& Kunnert, A. (2009). The impact of human capital on regional labour productivity in Europe. Letters in Spatial and Resource Sciences, 2(2):97108. DOI:

https://doi.org/10.1007/s12076-009$\underline{0027-7}$

Graham, J.W., \& Webb, R.H. (1979). Stocks and depreciation of human capital: New evidence from a present-value perspective. Review of Income and Wealth, 25(2):209-224.

Hanushek, E.A., \& Woessmann, L. (2011). How much do educational outcomes matter in OECD countries? Economic Policy, 26(67): 427-491. https://www.nber.org/system/files/worki ng_papers/w16515/w16515.pdf

Holz, C.A., \& Sun, Y. (2018). Physical capital estimates for China's provinces, 1952-2015 and beyond. China Economic Review, 51:342-357. DOI:

https://doi.org/10.1016/j.chieco.2017.06 .007

Jamison, E.A., Jamison, D.T., \& Hanushek, E. A. (2007). The effects of education quality on income growth and mortality decline. Economics of Education Review, 26(6):771-788. DOI:

https://doi.org/10.1016/j.econedurev.20 $\underline{07.07 .001}$

Jorgenson, D., \& Fraumeni, B.M. (1989). The Accumulation of Human and Nonhuman capital, 1948-1984. Chicago: University of Chicago Press. ISBN: 0226-48468-8.

Kendrick, J.W. (1976). The formation and stocks of total capital. New York: Columbia University Press for NBER. ISBN: 0-87014-271-2.

LeSage, J.P., \& Pace, R.K. (2009). Introduction to spatial econometrics. New 
Zhao \& Du. Higher Education, Human Capital Quality and "Local-Neighborhood" Economy.

York: CRC Press. ISBN: 978-142-006424-7.

Li, H., \& Tang, T. (2015). Regional differences in labor quality based on human capital. Journal of Central University of Finance \& Economics, 35(8):72-80+86. [Chinese]

http://www.iyonly.com/xbbjb.iyonly.co $\underline{\mathrm{m} / \mathrm{CN} / \text { article/downloadArticleFile.do?at }}$ tachType=PDF\&id $=5802$

Li, T., Lai, J.T., Wang, Y., \& Zhao, D. (2016). Long-run relationship between inequality and growth in post-reform China: New evidence from dynamic panel model. International Review of Economics \& Finance, 41:238 -252. DOI: https://doi.org/10.1016/j.iref.2015.08.00 $\underline{9}$

Liang, R., Yu, J., \& Feng, S. (2015). The calculation of the contribution of human capital to China's economic growth. South China Journal of Economics, 33(7):1-14. [Chinese] DOI:

https://doi.org/10.19592/j.cnki.scje.2015 .07 .001

Lucas Jr, R.E. (1988). On the mechanics of economic development. Journal of Monetary Economics, 22(1):3-42. DOI: https://doi.org/10.1016/03043932(88)90168-7

Meng, W., \& Wang, X. (2014). China's provincial-level of human capital measurement-based on the cost method of perpetual inventory technology. Studies in Labor Economics, 2(4):141-160.

[Chinese]

https://www.cnki.com.cn/Article/CJFD Total-LDJJ201404009.htm

Mulligan, C.B., \& Sala-i-Martin, X. (1997). A labor-income-based measure of the value of human capital: An application to the United States. Japan and the World Economy, 9(2):159-191. DOI:
https://doi.org/10.1016/S09221425(96)00236-8

Nelson, R.R., \& Phelps, E.S. (1965). Investment in humans, technological diffusion, and economic growth. Cowles Foundation Discussion Papers 189, Cowles Foundation for Research in Economics, Yale University. https://ideas.repec.org/p/cwl/cwldpp/18 9.html

Psacharopoulos, G., \& Patrinos, H.A. (2004). Returns to investment in education: A further update. Education Economics, 12(2):111-134. DOI:

https://doi.org/10.1080/0964529042000 $\underline{239140}$

Qian, X. (2012). A statistical estimation of human capital level. Statistical Research, 29(8):74-82. [Chinese] DOI: https://doi.org/10.19343/j.cnki.111302/c.2012.08.013

Romer, P. M. (1990). Endogenous technological change. Journal of Political Economy, 98(5):71-102.

https://www.journals.uchicago.edu/doi/a bs/10.1086/261725

Schultz, T.W. (1961). Investment in Human Capital. The American Economic Review, 51(1):1-17.

https://www.jstor.org/stable/1818907?se $\mathrm{q}=1$

Zhang, T., Li, J., \& Zhou, H. (2016). Regional knowledge spillovers, collaborative innovation, and total factor productivity growth in high-tech industries. $F i$ nance and Trade Research, 27(1):9-18.

[Chinese] DOI: https://doi.org/10.19337/j.cnki.341093/f.2016.01.002

Zhu, P., \& Xu, D. (2007). Estimation of human capital in Chinese cities. Economic Research Journal, 53(9):84-95.

[Chinese]

https://www.2002n.com/d/img/upfiles_6 /200849153137197.pdf 
Zhao \& Du. Higher Education, Human Capital Quality and "Local-Neighborhood" Economy.

Received: 10 April 2021

Revised: 20 April 2021

Accepted: 09 May 2021

The Chinese version of this article has been published in Higher Education Research, 2020, 41(8):5262. The English version has been authorized for being publication in BECE by the author(s) and the Chinese journal.

赵冉, 杜育红. (2020). 高等教育, 人力资本质量对“本地-邻地”经济增长的影响. 高等教育研究, 2020, 41(8):52-62. 